\title{
Vulvovajinal Enfeksiyon Tanı Yöntemlerinin Karşılaştırılması ve Predispozan Faktörlerin Etkilerinin İncelenmesi
}

\author{
Hilal TÜRKMEN ALBAYRAK ${ }^{1}$, Alper Murat ALBAYRAK ${ }^{2}$, \\ Ayfer BAKIR ${ }^{1}$, İdris ŞAHIN in $^{3}$
}

\section{ÖZ}

Amaç: Vulvovajinal enfeksiyonlara sebep olan en önemli mikrobiyal etkenler Candida türleri, Trichomonas vaginalis, Gardnerella vaginalis, enterobakteriler, stafilokoklar, enterokoklar ve B grubu streptokoklardır. Bu çalışmanın amacı vulvovajinal enfeksiyonların tanısında kullanılan yöntemleri karşılaştırarak, enfeksiyon prevalansını ve predispozan faktörlerin etkilerini belirlemektir.

Gereç ve Yöntemler: Bu çalışmaya yaşları 18-60 arasında değişen 300 kadın hasta dahil edildi. T. vaginalis, bakteriyel vajinoz ve Candida türleri tanıları için direkt bakı, Gram ve Giemsa boya, kültür yöntemleri kullanıldı.

Bulgular: Hastaların \%35,3'ünde bakteriyel vajinoz, \%28,3'ünde T. vaginalis, \%28'inde Candida türleri saptandı. Bakteriyel vajinoz için Gram boya yöntemi referans test olarak alındığında direkt bakının duyarlılığı \%72,6, $T$. vaginalis için direkt bakı yöntemi referans test olarak alındığında Gram boyanın duyarlılı̆ı \%95,3; Giemsa boyanın duyarlılığ $1 \% 68,2$, Candida türleri için kültür yöntemi referans test olarak alındığında direkt bakının duyarlılığı \%42,9; Gram boyanın duyarlılığı \%60,7 olarak belirlenmiştir. Özgüllükleri ise tüm yöntemler için \%100 olarak bulundu. C. albicans en fazla saptanan Candida türüydü. Korunma yöntemi kullanmamanın T. vaginalis enfeksiyonu için risk faktörü olduğu belirlendi.

Sonuç: Vulvovajinal enfeksiyonların tanısında tanı yöntemlerinin duyarlılık ve özgüllükleri dikkate alındığında, hiçbir testin tek başına yeterli olmadığını düşünmekteyiz. Hastaya ait epidemiyolojik ve klinik bulguların yanı sıra, direkt bakı, Gram boya ve kültür yöntemlerinin bir arada uygulanmasının daha güvenilir sonuç vereceği kanısındayız.

Anahtar Kelimeler: Vulvovajinal enfeksiyon; trichomonas vaginalis; bakteriyel vajinoz; candida albicans; prevalans.

\section{Comparison of Vulvovaginal Infection Diagnostic Methods and Effects of Predisposing Factors Vulvovaginal Infections}

\begin{abstract}
Aim: The most important microbial factors that are caused vulvovaginal infections, are Candida species, Trichomonas vaginalis, Gardnerella vaginalis, enterobacteria, staphylococci, enterococci and group B streptococci. The aim of this study is to determine the prevalence of the infection and the effects of predisposing factors by comparing the methods used in the diagnosis of vulvovaginal infections.

Material and Methods: A total of 300 female patients between the ages of 18-60 were included in this study. For the diagnosis of $T$. vaginalis, bacterial vaginosis and Candida species, direct examination, Gram and Giemsa stain, culture methods were used.

Results: Bacterial vaginosis was found in $35.3 \%$, T.vaginalis in $28.3 \%$, Candida spp. in $28 \%$. Gram stain method was taken as the reference test for the bacterial vaginosis sensitivity of direct examination was found $72.6 \%$. Direct examination method was taken as the reference test for the T. vaginalis sensitivity of Gram stain was found $95.3 \%$ and Giemsa stain $68.2 \%$. Culture method was taken as the reference test for the Candida species sensitivity of direct examination was found $42.9 \%$ and Gram stain $60.7 \%$; specificity was found to be $100 \%$ for all methods. C.albicans was found the most common type of Candida. It was determined that not using prevention method was a risk factor for
\end{abstract}

1 Sağlık Bilimleri Üniversitesi, Gülhane Eğitim ve Araştırma Hastanesi, Tıbbi Mikrobiyoloji Kliniği, Ankara, Türkiye

2 Düzce Atatürk Devlet Hastanesi, Kadın Hastalıkları ve Doğum Kliniği, Düzce

3 Düzce Üniversitesi, Tıp Fakültesi, Tıbbi Mikrobiyoloji Anabilim Dalı, Düzce

Sorumlu Yazar / Corresponding Author: Hilal TÜRKMEN ALBAYRAK, e-mail: hilal.turkmen@hotmail.com

Geliş Tarihi / Received: 29.04.2019, Kabul Tarihi / Accepted: 11.12.2019 


\section{T. vaginalis infection.}

Conclusion: We think that none of the tests are sufficient alone in the diagnosis of vulvovaginal infections when the sensitivity and specificity of the methods are considered. In order to get more reliable results, direct examination, culture and Gram staining should be applied, addition to patient's clinical condition and epidemiology.

Keywords: Vulvovaginal infection; trichomonas vaginalis; bacterial vaginosis; candida albicans; prevalence.

\section{GÍRIS}

Vajinal bölgede enfeksiyonlara sebep olan en önemli mikrobiyal etkenler arasında Candida türleri, Trichomonas vaginalis, Gardnerella vaginalis, enterobakteriler, stafilokoklar, enterokoklar ve B grubu streptokoklar yer almaktadır (1). Literatür çalışmaları incelendiğinde semptomatik kadınların \%22-50'sinde bakteriyel vajinoz (BV), \%17-39'unda Candida türleri, \%4-35'inde T.vaginalis saptandığ 1 ve semptomlu kadınların \%30'unda ise tanı konulamadığ bildirilmektedir (2).

BV, kadınların \%30'unda görülen en yaygın vajinal akıntı veya kötü koku kaynağıdır. BV'li kadınların \%50'sinden fazlası semptomsuzdur (2). Anaerobik bakterilerin, amin üretiminden kaynaklanan balık kokusu BV'yi düşündürmektedir. Vajinal akıntı homojen, şeffaf, beyaz veya gri renkte olabilir. BV'de, vajinal mukozal inflamasyon görülmez, nadiren ağrı ve vulvar kaşıntıya neden olmaktadır $(3,4)$. Klinik pratikte BV, dört Amsel kriterlerinden üçünün varlığıyla teşhis edilir. Bu kriterler; homojen vajinal akıntı, vajinal $\mathrm{pH} 4,5$ 'ten büyük, \%10 $\mathrm{KOH}$ (potasyum hidroksit) çözeltisi eklendiğinde balık kokusu ve en az \%20 oranında ipucu hücreleri (clue cell) tespit edilmesidir. Amsel kriterlerinin, BV'de duyarlılığ $\%$, özgüllüğü \%93 olarak bildirilmiştir $(5,6)$. BV tanısında kullanılan Nugent kriterlerine göre; Grade 0; hiçbir ajan içermeyen yayma, Grade 1; normal Lactobacillus hakimiyeti (Nugent Skoru <4), Grade 2; ara flora (Nugent Skor4-6), Grade 3; G. vaginalis ve diğer anaerob bakterilerin hakimiyeti ve Lactobacillus eksikliği ile karakterize tipik BV florasını (Nugent skor $>6$ ) ifade etmektedir (7). Sadece BV varlığında, vajinal akıntı örneklerinde daha az lökosit tespit edilmektedir. Lökosit sayıs1, her büyütme alanında (x40 büyütmede) 5 adetten fazla ise, BV'nin yanında inflamatuar bir süreç söz konusudur (6).

T. vaginalis, monoksen kamçılı bir protozoon olup cinsel yolla bulaşır. Bununla birlikte ortak kullanılan yüzme havuzları ve alafranga tuvaletlerin de bulaşta rol oynadığı bildirilmektedir (8). Trikomoniyazisin semptom ve belirtileri spesifik değildir ve mikroskopi ile tanı koymak daha güvenilirdir. Trikomoniyazisi düşündüren özellikler, mikroskopik incelemede epitel hücrelerinden daha fazla sayıda lökosit bulunması, vajinal pH'nın 4,5'ten daha yüksek olduğu durumlarda hareketli trikomonasların görülmesidir (2). Direkt bakı hızlı, ucuz bir yöntemdir ve duyarlılık \%58-82 arasında değişmektedir. Duyarlılık oranları, incelemeye alınma süresi, incelemeyi yapan kişinin tecrübesi ve vajinal sıvıdaki parazit sayısından da etkilenmektedir (9).
Vulvovajinal kandidiyoz (VVK) genellikle endojen kökenlidir ve cinsel yolla bulaşan bir enfeksiyon olarak kabul edilmez. Kadınların \%75'inin hayatları boyunca en az bir defa, \%40-45'inin ise iki ya da daha fazla sayıda VVK atağı geçirdiği tahmin edilmektedir (10). Kaşıntı şikâyeti en belirgin semptomdur. VVK semptomları ve belirtileri enfeksiyona özgü olmadığ 1 için, maya varlığını tespit etmek için direkt preparat, \%10'luk $\mathrm{KOH}$ preparatı kullanılır. KOH ile incelemenin duyarlılığ $\% 65-85$ arasındadır. Vajinal pH genellikle normaldir. Artmış pH, BV veya $T$. vaginalis gibi mikst enfeksiyonu düşündürmektedir (2,11). VVK'lı semptomlu hastaların, yaklaşık \%50'sinde mikroskobi negatiftir. Bu nedenle, negatif mikroskobi ve normal pH'lı semptomatik kadınlarda vajinal kültür yapılmalıdır. Vajen kültürü, semptomları tekrarlayan kadınlarda da önerilmektedir (11). İzole edilen maya suşlarının \%85-95’i C. albicans türüne aittir. Diğer türler arasında en yaygın olanı $C$. glabrata'dır $(10,12,13)$.

Bu çalışmada Kadın Hastalıkları ve Doğum polikliniğgine başvuran hastalarda, vulvovajinal enfeksiyon etkenlerinin dağılımı ve sıklığı, tanıda kullanılan yöntemlerin karşılaştırılması ve predispozan faktörlerin etkilerinin araştırılması amaçlanmıştır.

\section{GEREC VE YÖNTEMLER}

$\mathrm{Bu}$ çalışma kesitsel bir araştırma olarak planlandı. Araştırmaya alınan gönüllüler, vajinal akıntısı olan hastalar ve akıntı dişında farklı jinekolojik şikâyetleri olan hastalardan oluşturuldu. Düzce Devlet Hastanesi, Kadın Hastalıkları ve Doğum polikliniğine Ekim 2010Aralık 2010 tarihleri arasında, jinekolojik şikâyetlerle başvuran ve çalışmaya katılmayı kabul eden yaşları 18-60 arasında değişen 300 kadın hasta dahil edildi. Her hastadan gönüllü onam formu doldurularak iki adet vajinal akıntı örneği alındı. Vajinal akıntı örneğinden biri steril serum fizyolojik içeren tüpe, diğeri modifiye Stuart mediumuna yerleştirildi. Bir dakika içinde birinci tüpteki örnek poliklinikte, direkt lam-lamel arasında 40X büyütme ile mikroskopik olarak incelendi. Tipik hareketlerinin görülmesi ile $T$. vaginalis tanısı konuldu. Direkt bakıda ipucu hücreleri, maya hücreleri ve lökosit varlığı değerlendirildi. Her bir örnek, Gram ve Giemsa boya yöntemleri ile incelendi. BV, Nugent kriterlerine göre değerlendirilirdi. Vajinal sıvının pH'sı, hazır $\mathrm{pH}$ şeridi (MerckCo, Darmstadt, Germany) kullanılarak belirlendi. Vajinal akıntı örneğinin bulunduğu tüpe \%10'luk $\mathrm{KOH}$ damlatılarak balık kokusu varlığı araştırıldı.

Bakteriyolojik identifikasyon için \%5 Koyun Kanlı Agar (HiMedia, India), Çikolata Agar (HiMedia, India) ve Eozin Metilen Blue Agar'a (HiMedia, India), Candida kültürü için Sabouraud Dekstroz Agar’a (HiMedia, India) ekim yapıldı. Saf kültür halinde ya da flora üyelerine göre baskın olarak üreyen mikroorganizmalar etken olarak değerlendirilerek standart mikrobiyolojik yöntemlerle (koloni morfolojisi, hemoliz, gram boya...) identifikasyon yapıldı. Candida türleri için Mısır unuTween 80 agar (Difco laboratories, Detroit, Mich, USA), CHROMagar kromojenik besiyeri (Biomerieux, Fransa), germ tüp testi kullanıldı. Predispozan faktörler anket formu ile araştırıldı. Bu çalışma için Düzce Üniversitesi Tıp Fakültesi Girişimsel Olmayan Klinik Araştırmalar 
Etik Komisyonu'ndan onay alındı (Etik kurul no: 2010/70).

\section{İstatistiksel Analiz}

Çalışmada elde edilen verilerin istatistiksel değerlendirmesinde Predictive Analytics Software (PASW) SPSS 18 paket programı kullanıldı. Verilerin analizinde tanımlayıcı istatistikler (sayı, yüzde ve ortalama) hesaplandı. Değişkenlerin normal dağılıma uygunluğu görsel yöntemler (histogram ve olasılık grafikleri) ve Kolmogorov-Smirnov testi ile incelendi. Predispozan faktörlerle vulvovajinal enfeksiyon gelişimi arasındaki ilişki Pearson Chi-Square ve Fisher Exact testleri ile araştırıldı. İstatistiksel anlamlılık düzeyi olarak $\mathrm{p}<0,05$ değeri alındı. BV tanısında Gram boya, $T$. vaginalis tanısında direkt bakı ve Candida türleri tanısında kültür "gold standart" olarak kabul edildi. Sonuçlar duyarlılık, özgüllük, pozitif prediktif değer (PPD) ve negatif prediktif değer (NPD) olarak değerlendirildi.

\section{BULGULAR}

Düzce Devlet Hastanesi, Kadın Hastalıkları ve Doğum polikliniğine jinekolojik şikâyetler ile başvuran 300 kadın hastanın medyan yaşı 34 (yaş aralığı:18-60) olarak bulundu. Hastaların \%35,3'ünde (106/300) BV, \%28,3'ünde (85/300) T. vaginalis, \%28'inde (84/300) Candida türleri tespit edildi (Şekil 1).

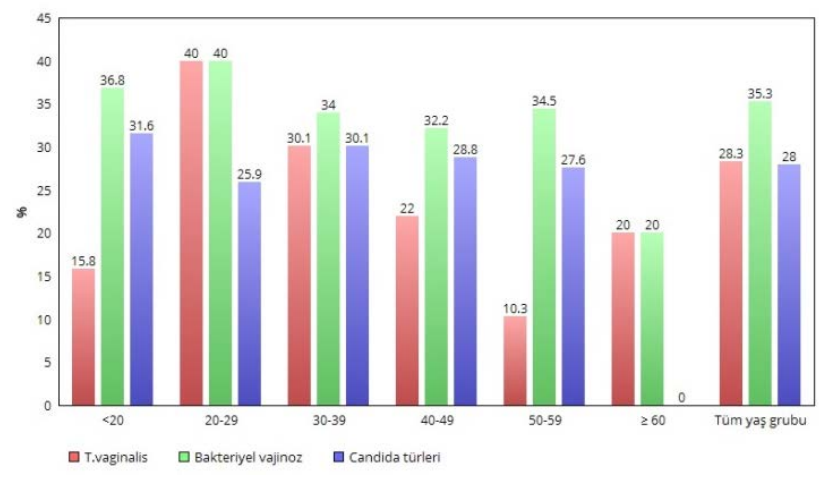

Şekil 1. Tüm yaş ve yaş gruplarına göre $T$. vaginalis, bakteriyel vajinoz, Candida türlerinin dağılım oranları

Yaş gruplarına göre etkenlerin dağılımı incelendiğinde $T$. vaginalis ve BV en fazla 20-29 yaş grubunda aynı oranlarda (\%40) saptand (sırasiyla; $\mathrm{p}=0,021, \mathrm{p}=0,890)$. Candida türleri ise en fazla 20 yaş altı grupta \%31,6 oranında bulundu ( $\mathrm{p}=0,776$, Tablo 1 ).

T. vaginalis'li hastaların 77'sinde akınt1, 51'inde disparanui; BV'li hastaların ise 92'sinde akıntı saptandı. Fark istatistiksel olarak anlamlı bulundu (sirasıyla; $\mathrm{p}=0,003, \mathrm{p}=0,035, \mathrm{p}=0,023$, Tablo 2).

Demografik özelliklere göre enfeksiyon etkenlerinin dağılımı Tablo 3'te sunuldu. Cinsel ilişki sayısı ile $T$. vaginalis, $\mathrm{BV}$ ve Candida türlerinin saptanma oranları arasında anlamlı ilişki bulundu $(\mathrm{p}<0,001$, Tablo 3). Ayrıca korunma yöntemi kullanmayanlarda T. vaginalis varlığının korunma yöntemi kullananlardan anlamlı şekilde daha yüksek olduğu saptand $1(\mathrm{p}<0,001$, Tablo 3$)$. Vajen $\mathrm{pH}>4,5$ değerleri $T$. vaginalis'te $(\% 98,8)$ ve BV'de $(\% 98,1)$ yüksek oranda ve anlamlı olarak tespit edildi $(\mathrm{p}=0,002)$. KOH testi BV'li kadınların \%65,1'inde diğer etkenlere göre daha yüksek oranda pozitif saptandı $(\mathrm{p}<0,001)$. Gram boyamada BV'li hastaların \%99'unda laktobasil oranının azaldığı, T. vaginalis'li hastaların ise $\% 96,5$ 'inde lökosit varlığının en yüksek oranda olduğu bulundu (sirasiyla; $\mathrm{p}<0,001, \mathrm{p}<0,001$, Tablo 4).

Tablo 1. Yaş gruplarına göre T. vaginalis, Bakteriyel vajinoz ve Candida türlerinin dağılımı

\begin{tabular}{|c|c|c|c|c|c|c|c|}
\hline \multirow{2}{*}{$\begin{array}{c}\text { Yaş } \\
\text { grubu }\end{array}$} & \multirow{2}{*}{ T. vaginalis } & \multicolumn{2}{|c|}{$\mathbf{B V}$} & \multicolumn{2}{c|}{$\begin{array}{c}\text { Candida } \\
\text { türleri }\end{array}$} & $\begin{array}{c}\text { Toplam } \\
\text { hasta } \\
\text { sayısı }\end{array}$ \\
\cline { 2 - 8 } & $\mathbf{n}$ & $\mathbf{\%}$ & $\mathbf{n}$ & $\mathbf{\%}$ & $\mathbf{n}$ & $\mathbf{\%}$ & 19 \\
\hline$<20$ & 3 & 15,8 & 7 & 36,8 & 6 & 31,6 & 85 \\
\hline $20-29$ & 34 & 40 & 34 & 40 & 22 & 25,9 & 85 \\
\hline $30-39$ & 31 & 30,1 & 35 & 34 & 31 & 30,1 & 103 \\
\hline $40-49$ & 13 & 22 & 19 & 32,2 & 17 & 28,8 & 59 \\
\hline $50-59$ & 3 & 10,3 & 10 & 34,5 & 8 & 27,6 & 29 \\
\hline$\geq 60$ & 1 & 20 & 1 & 20 & - & - & 5 \\
\hline \multirow{2}{*}{$\mathbf{0}$} & $\mathbf{0 , 0 2 1}$ & \multicolumn{7}{|c|}{0,890} & \multicolumn{7}{|c|}{0,776} & 300 \\
\hline
\end{tabular}

Vajen $\mathrm{pH}>4,5$ değerleri $T$. vaginalis'te $(\% 98,8)$ ve BV'de $(\% 98,1)$ yüksek oranda ve anlamlı olarak tespit edildi $(\mathrm{p}=0,002)$. KOH testi BV'li kadınların \%65,1'inde diğer etkenlere göre daha yüksek oranda pozitif saptandı ( $<0,001)$. Gram boyamada BV'li hastaların \%99'unda laktobasil oranının azaldığ $1, T$. vaginalis'li hastaların ise \%96,5'inde lökosit varlığının en yüksek oranda olduğu bulundu (sirasiyla; $\mathrm{p}<0,001, \mathrm{p}<0,001$, Tablo 4).

BV tanısında Gram boya yöntemi referans test olarak alındı ve direkt bakının duyarlılık ve özgüllük değerleri sırasıyla \%72,6 (77/106) ve \%100 bulundu. T. vaginalis tanısı için direkt bakı referans test kabul edildi. Gram ve Giemsa boya yönteminin duyarlılıkları sırasıyla \%95,3 (81/85) ve \%68,2 (58/85), her iki yöntemin özgüllüklerinin ise $\% 100$ olduğu belirlendi. Candida türleri için de kültür yöntemi referans test olarak kabul edildiğinde direkt bakı ve Gram boya duyarlılıkları sirasiyla \%42,9 (36/84) ve \%60,7 (51/84) her iki yöntemin özgüllüklerinin ise $\% 100$ olduğu tespit edildi (Tablo 5).

\section{TARTIŞMA}

Vulvovajinal enfeksiyonların semptomları özgül değildir. Kadın Hastalıkları ve Doğum polikliniğine başvuran kadınlarda en sık rastlanılan semptomlar arasında vajinal akıntı ve yanma şikâyeti bulunmakla birlikte, vajinal akıntısı olan kadınların hepsinde enfektif bir etiyoloji söz konusu değildir. Enfeksiyöz nedenlerin \%90'ını BV, trikomoniyazis ve VVK oluşturmaktadır. Semptomlar ayırıcı tanı için yeterli değildir $(14,15)$.

İzmir'de vajinal yakınmalı 231 hastayı içeren bir araştırmada, \%26 nonspesifik vajinit, \%23,8 BV, \%24,7 Candida vajiniti, \%6,1 trikomonas vajiniti tespit edilmiştir (16). Ankara'da 100 vajinal örneğin değerlendirildiği bir çalışmada ise, vajinal akıntı etkeni olarak hastaların \%42'sinde Candida, \%9'unda $G$. vaginalis, \%8'inde E. coli, \%2'sinde T. vaginalis, \%2'sinde S. aureus, \%1'inde Klebsiella türleri saptanmıştır (17). Bahram ve ark. (18) BV, trikomoniyazis ve VVK'y1 sirasına gore \%16,2, \%6,6, $\% 4,8$; Shandong ve ark. (19) \%6,6, \%2,9, \%3,9; Hamedan ve ark. (20) \%28,5, \%18,1, \%17,2; 
Tablo 2. Enfeksiyon etkenlerine göre şikâyetlerin dağılımı

\begin{tabular}{|c|c|c|c|c|c|c|c|}
\hline Şikâyet & $\begin{array}{c}\ddagger T V \\
(n=85)\end{array}$ & 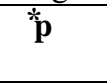 & $\begin{array}{l}\text { PBV } \\
(n=106)\end{array}$ & 辛 & $\begin{array}{c}\text { Candida türleri } \\
(\mathrm{n}=84)\end{array}$ & 产 & Toplam \\
\hline Akıntı & 77 & 0,003 & 92 & 0,023 & 70 & 0,325 & 239 \\
\hline Kaşıntı & 41 & 0,147 & 51 & 0,094 & 33 & 0,601 & 125 \\
\hline Dizüri & 39 & 0,864 & 57 & 0,068 & 44 & 0,216 & 140 \\
\hline Disparanui & 51 & 0,035 & 56 & 0,522 & 44 & 0,658 & 151 \\
\hline
\end{tabular}

*Pearson ki-kare, ${ }^{*}$ T.vaginalis, 'Bakteriyel vajinoz

Tablo 3. Demografik özelliklere göre enfeksiyon etkenlerinin dağılımı

\begin{tabular}{|c|c|c|c|c|c|c|c|c|c|c|}
\hline \multirow{2}{*}{\multicolumn{2}{|c|}{ Demografik özellikler }} & \multicolumn{3}{|c|}{ T. vaginalis } & \multicolumn{3}{|c|}{ BV } & \multicolumn{3}{|c|}{ Candida türleri } \\
\hline & & Var & Yok & 常 & Var & Yok & $\%$ & Var & Yok & 常 \\
\hline \multirow{2}{*}{$\begin{array}{l}\text { Eğitim } \\
\text { durumu }\end{array}$} & Lise altı & 68 & 185 & \multirow[b]{2}{*}{0,194} & 91 & 162 & \multirow[b]{2}{*}{0,593} & 76 & 177 & \multirow[b]{2}{*}{0,068} \\
\hline & Lise ve üstü & 17 & 30 & & 15 & 32 & & 8 & 39 & \\
\hline \multirow{2}{*}{$\begin{array}{l}\text { Çalışma } \\
\text { durumu }\end{array}$} & Ev kadını & 69 & 172 & \multirow[b]{2}{*}{0,817} & 88 & 153 & \multirow[b]{2}{*}{0,387} & 71 & 170 & \multirow[b]{2}{*}{0,255} \\
\hline & Çalışan & 16 & 43 & & 18 & 41 & & 13 & 46 & \\
\hline \multirow{2}{*}{$\begin{array}{l}\text { Medeni } \\
\text { durum }\end{array}$} & Evli & 80 & 204 & \multirow[b]{2}{*}{$* * 0,780$} & 102 & 182 & \multirow[b]{2}{*}{$* 0,374$} & 77 & 207 & \multirow[b]{2}{*}{$* * 0,160$} \\
\hline & \#Diğer & 5 & 11 & & 4 & 12 & & 7 & 9 & \\
\hline \multirow{2}{*}{$\begin{array}{l}{ }^{\S} \text { Cinsel } \\
\text { ilişki sayısı }\end{array}$} & İkiden fazla & 25 & 121 & \multirow[b]{2}{*}{$<\mathbf{0 , 0 0 1}$} & 30 & 116 & \multirow[b]{2}{*}{0,007} & 28 & 118 & \multirow[b]{2}{*}{$<\mathbf{0 , 0 0 1}$} \\
\hline & İkiden az & 60 & 94 & & 6 & 78 & & 56 & 98 & \\
\hline \multirow{2}{*}{$\begin{array}{l}\text { Korunma } \\
\text { yöntemi }\end{array}$} & Kullanan & 57 & 123 & \multirow[b]{2}{*}{$<0,001$} & 66 & 114 & \multirow[b]{2}{*}{0,554} & 52 & 128 & \multirow[b]{2}{*}{0,675} \\
\hline & Kullanmayan & 128 & 92 & & 40 & 80 & & 32 & 88 & \\
\hline
\end{tabular}

Pearson ki-kare, ${ }^{* *}$ Fisher Exact test, 'bakteriyel vajinoz, ${ }^{*}$ bekâr, eşinden ayrılmış, erkek arkadaşı var, ${ }^{\S}$ haftada,

${ }^{\ddagger}$ oral kontraseptif, rahim içi araç, kondom, diğer yöntemler

Tablo 4. Enfeksiyon etkenlerinin $\mathrm{pH}, \mathrm{KOH}$, laktobasil ve lökosit yönünden değerlendirilmesi

\begin{tabular}{|c|c|c|c|}
\hline Test parametre & T. vaginalis & BV & Candida türleri \\
\hline $\mathrm{pH}$ & Sayı (\%) & Sayı (\%) & Sayı (\%) \\
\hline $\mathrm{pH}>4,5$ & $84(98,8)$ & $104(98,1)$ & $74(88,1)$ \\
\hline $\mathrm{pH}<4,5$ & $1(1,2)$ & $2(1,9)$ & $10(11,9)$ \\
\hline$* * \mathrm{p}$ & \multicolumn{3}{|c|}{0,002} \\
\hline \multicolumn{4}{|l|}{$\neq \mathrm{KOH}$} \\
\hline $\mathrm{KOH}$ pozitif & $33(38,8)$ & $69(65,1)$ & $23(27,4)$ \\
\hline $\mathrm{KOH}$ negatif & $52(61,2)$ & $37(34,9)$ & $61(72,6)$ \\
\hline 常 & \multicolumn{3}{|c|}{$<0,001$} \\
\hline \multicolumn{4}{|l|}{ Laktobasil } \\
\hline Normal & $12(14,1)$ & $1(0,9)$ & $19(22,6)$ \\
\hline Yok/azalmış & $62(72,9)$ & $105(99,0)$ & $59(70,2)$ \\
\hline Artmış & $11(12,9)$ & - & $6(7,1)$ \\
\hline${ }^{* *} \mathrm{p}$ & \multicolumn{3}{|c|}{$<0,001$} \\
\hline \multicolumn{4}{|l|}{ Lökosit } \\
\hline Var & $82(96,5)$ & $51(48,1)$ & $45(53,6)$ \\
\hline Yok & $3(3,5)$ & $55(51,9)$ & $39(46,4)$ \\
\hline$* * \mathrm{p}$ & \multicolumn{3}{|c|}{$<0,001$} \\
\hline
\end{tabular}

Tablo 5. Bakteriyel vajinoz, T. vaginalis ve Candida türleri tanı yöntemlerinin referans yöntemlerle karșılaștırılması

\begin{tabular}{|c|c|c|c|c|c|}
\hline Etken & BV & \multicolumn{2}{|c|}{ T. vaginalis } & \multicolumn{2}{c|}{ Candida türleri } \\
\hline Referans test & Gram boya & \multicolumn{2}{|c|}{ Direkt bakı } & \multicolumn{2}{c|}{ Kültür } \\
\hline Tanı yöntemi & Direkt bakı & $\begin{array}{c}\text { Gram } \\
\text { boya }\end{array}$ & Giemsa boya & Direkt bakı & $\begin{array}{c}\text { Gram } \\
\text { boya }\end{array}$ \\
\hline Yanlış pozitif örnek sayısı & 0 & 0 & 0 & 0 & 0 \\
\hline Gerçek negatif örnek sayısı & 198 & 194 & 217 & 239 & 224 \\
\hline Duyarlılık \% (n) & 72,6 & 95,3 & 68,2 & 42,9 & 60,7 \\
$(77 / 106)$ & $(81 / 85)$ & $(58 / 85)$ & $(36 / 84)$ & $(51 / 84)$ \\
\hline Özgüllük (\%) & 100 & 100 & 100 & 100 & 100 \\
\hline Pozitif prediktif değer (\%) & 100 & 100 & 100 & 100 & 100 \\
\hline Negatif prediktif değer (\%) & 87,2 & 98,1 & 88,8 & 81,8 & 86,7 \\
\hline
\end{tabular}

Bakteriyel vajinoz 
Vientiane ve ark. (21) \%24,5, \%3,7 ve \%39,5; Oliveira ve ark. (22) \%20, \%4,1, \%12,5 olarak tespit etmişlerdir. Bu çalışmada ise jinekolojik şikâyetlerle başvuran hastaların \%35,3'ünde (106/300) BV, \%28,3'ünde (85/300) $T$. vaginalis, \%28'inde (84/300) Candida türleri saptand. Tespit edilen bu yüksek oranların, çalışmaya dahil edilen hastaların sosyodemografik yapıları, alınan örneklerin sayısı ve mikroskobik inceleme süresi ile ilişkili olabileceğini düşünmekteyiz.

Thulkar ve ark. (23) yaptıkları çalışmada $\mathrm{pH}$ ve $\mathrm{KOH}$ testlerinin vajinal enfeksiyonun tanısını desteklediğini bildirmişlerdir. Bezircioğlu ve ark. (16) 4,5'ten büyük pH değeri ile birlikte, laktobasil yokluğunun BV'yi desteklediğini saptamışlardır. Bu çalışmada da BV'li hastaların \%98,1'inde $\mathrm{pH}$ değeri $>4,5$, laktobasil azlığı ve yokluğu \%99 olarak bulundu (Tablo 4).

BV tanısında altın standart Gram boya ve Nugent skorlamasıdır. Nugent skorlamasının BV tanısında duyarlılığının \%93-97 oranında olduğu bildirilmektedir (24). Bu çalışmada da Gram boya duyarlılığı BV için $\% 100$ bulundu.

BV, kadınlarda vajinal akıntı ve kokunun en yaygın nedenidir (25). Bu çalışmada BV'li hastaların 92'sinde akıntı saptandı ( $\mathrm{p}=0,023$, Tablo 2$)$. $T$. vaginalis tanısında direkt bakı, en s1k kullanılan kolay uygulanabilen, ucuz ve çabuk sonuç veren bir yöntemdir. Ülkemizde yapılan çalışmalarda direkt bakı ile etkenin saptanma oranları \%5,45-40,3 arasında bildirilmiştir $(26,27)$. Bu çalışmada da direkt bak1 ile $T$. vaginalis saptanma oranı \%28,3 $(85 / 300)$ ile diğer çalışmalarla uyumlu bulunmuştur. Yapılan diğer çalışmalarda $T$. vaginalis için direkt bakı, Gram boya, Giemsa boya yöntemlerinin duyarlılıkları sırasıyla \%7-75,8, \%15,2, \%5-48,5 tespit edilmiştir $(28,29)$. Bu çalışmada ise duyarlılık oranları sırasıyla $\% 100$, \%95,3, \%68,2 bulundu (Tablo 5). Duyarlılık oranlarının yüksek bulunması her hastadan iki örnek alınmasına ve bekletilmeden değerlendirmenin yapılmasına bağlanmıştır.

VVK tanısı rutinde kültür ve mikroskobik bakı olmaksızın klinik muayene ile konulmaktadır. VVK'da ana semptom kaşıntı olmasına rağmen bu çalıșmada 84 kandidiyoz hastasının 51'inde vajinal kaşıntı yakınması tespit edilmedi. Her ne kadar literatürlerde Candida enfeksiyonlarında başlıca klinik yakınmanın kaşıntı olduğu bildirilmekte ise de, diğer vajinal enfeksiyonlarda olduğu gibi semptomlar hastalığın tanısının konulmasında yol gösterici olmamakta ve laboratuvar tanı metotlarının kullanılması gerekmektedir.

Sonuç olarak vulvovajinal enfeksiyonların tanısında tanı yöntemlerinin duyarlılık ve özgüllükleri dikkate alındığında, hiçbir testin tek başına yeterli olmadığını düşünmekteyiz. Hastaya ait epidemiyolojik ve klinik bulguların yanı sıra, direkt bakı, Gram boya ve kültür yöntemlerinin bir arada uygulanmasının daha güvenilir sonuç vereceği kanısındayız.

\section{KAYNAKLAR}

1. Lowe NK, Neal JL, Ryan-Wenger NA. Accuracy of the clinical diagnosis of vaginitis compared to a DNA probe laboratory standard. Obstet Gynecol. 2009; 113(1): 89-95.
2. Anderson MR, Klink K, Cohrssen A. Evaluation of vaginal complaints. JAMA. 2004; 291(11): 1368-79.

3. Livengood III CH, Thomason JL, Hill GB. Bacterial vaginosis: diagnostic and pathogenetic findings during topical clindamycin therapy. Am J Obstet Gynecol. 1990; 163(2): 515-20.

4. Ness RB, Hillier SL, Kip KE, Soper DE, Stamm CA, McGregor JA, et al. Bacterial vaginosis and risk of pelvic inflammatory disease. Obstet Gynecol. 2004; 104(4): 761-9.

5. Hainer BL, Gibson MV. Vaginitis. Am Fam Physician. 2011; 83(7): 807-15.

6. Amsel R, Totten PA, Spiegel CA, Chen KC, Eschenbach D, Holmes KK. Nonspecific vaginitis: diagnostic criteria and microbial and epidemiologic associations. Am J Med. 1983; 74(1): 14-22.

7. Nugent RP, Krohn MA, Hillier SL. Reliability of diagnosing bacterial vaginosis is improved by a standardized method of gram stain interpretation. J Clin Microbiol. 1991; 29(2): 297-301.

8. Akdemir C, Keskin N, Çoksüer H. Kütahya'da vajinal akıntılı olgularda Trichomonas vaginalis görülme sıklığının klasik mikroskobi ve DNA hibridizasyon yöntemleriyle araştırılması. Türk Hijyen ve Deneysel Biyoloji Dergisi. 2010; 67(4): 161-6.

9. Wiese W, Patel SR, Patel SC, Ohl CA, Estrada CA. A meta-analysis of the Papanicolaou smear and wet mount for the diagnosis of vaginal trichomoniasis. Am J Med. 2000; 108(4): 301-8.

10. Corsello S, Spinillo A, Osnengo G, Penna C, Guaschino S, Beltrame A, et al. An epidemiological survey of vulvovaginal candidiasis in Italy. Eur J Obstet Gynecol Reprod Biol. 2003; 110(1): 66-72.

11. Sobel JD. Vulvovaginal candidosis. The Lancet. 2007; 369(9577): 1961-71.

12. Buscemi L, Arechavala A, Negroni R. Study of acute vulvovaginitis in sexually active adult women, with special reference to candidosis, in patients of the Francisco J. Muniz Infectious Diseases Hospital. Rev Iberoam Micol. 2004; 21(4): 177-81.

13. Denning DW, Kneale M, Sobel JD, RautemaaRichardson R. Global burden of recurrent vulvovaginal candidiasis: a systematic review. Lancet Infect Dis. 2018; 18(11): 339-47.

14. Friedrich EG Jr. Vaginitis. Am J Obstet Gynecol. 1985; 152(3): 247-51.

15. Mashburn J. Vaginal infections update. J Midwifery Womens Health. 2012; 57(6): 629-34.

16. Bezircioğlu İ, Öniz A. Vajinal akıntı yakınması ile başvuran hastaların akıntı örneklerinin direkt mikroskobik değerlendirilmesi. STED. 2004; 3(11): 422-5.

17. Kaymak Y, Paşaoğlu A, Erhan M, Çelik B. Polikliniğimize vajinit yakınmasıyla başvuran hastalarda vajinal akıntı etkenlerinin araştırılması. Gazi Medical Journal. 2005; 16(3): 114-20.

18. Bahram A, Hamid B, Zohre T. Prevalence of bacterial vaginosis and impact of genital hygiene practices in non-pregnant women in Zanjan, Iran. Oman Med J. 2009; 24(4): 288-93.

19. Fang X, Zhou Y, Yang Y, Diao Y,Li H. Prevalence and risk factors of trichomoniasis, bacterial vaginosis, and 
candidiasis for married women of child- bearing age in rural Shandong. Jpn J Infect Dis. 2007; 60(5): 25761.

20. Shobeiri F, Nazari M. A prospective study of genital infections in Hamedan, Iran. Southeast Asian J Trop Med Public Health. 2006; 37(3): 174-7.

21. Sihavong A, Phouthavane T, Lundborg C, Sayabounthavong K, Syhakhang L, Wahlstrom R. Reproductive tract infections among women attending a gynecology outpatient department in Vientiane, Lao PDR. Sex Transm Dis. 2007; 34(10): 791-5.

22. Oliveira F, Pfleger V, Lang K, Heukelbach J, Miralles I, Fraga F, et al. Sexually transmitted infections, bacterial vaginosis and candidiasis in women of reproductive age in rural Northeast Brazil: a population-based study. Mem Inst Oswaldo Cruz. 2007; 102(6): 751-6.

23. Thulkar J, Kriplani A, Agarwal N. Utility of pH test \& whiff test in syndromic approach of abnormal vaginal discharge. Indian J Med Res. 2010; 131: 4458.

24. Anukam K, Idemoh C, Olise N. Evaluation of bacterial vaginosis using nugent scoring system. Journal of Medicine and Biomedical Research. 2014; 13(1): 25-32.

25. Bradshaw CS, Vodstrcil LA, Hocking JS, Law M, Pirotta M, Garland SM, DeGuingand D, Morton AN, Fairley CK. Recurrence of bacterial vaginosis is significantly associated with posttreatment sexual activities and hormonal contraceptive use. Clin Infect Dis. 2013; 56(6): 777-86.

26. Ertabaklar H, Ertuğ S, Kafkas S, Odabaşı A, Karataş E. Vajinal akıntılı olgularda trichomonas vaginalis araştırılması. Türkiye Parazitoloji Dergisi. 2004; 28(4): 181-4.

27. Suay A, Yayla M, Mete Ö, Elçi S. 300 hayat kadınında direkt mikroskopi ve kültür yöntemleriyle Trichomonas vaginalis ve buna bağlı olarak trikomoniyaz'ın araştırılması. Türkiye Parazitoloji Dergisi. 1995; 19(2): 170-3.

28. Kilimcioglu A, Laçin S, Girginkardeşler N, Değerli K, Özbilgin A. Trichomoniasis tanısında direkt mikroskobi ve kültür yöntemlerinden Diamond, Thioglucolate TYM, CLPM besiyerlerinin karşılaştırılması. Türkiye Parazitoloji Dergisi. 1998; 22(3): 239-42.

29. El Sayed Zaki M, Raafat D, El Emshaty W, Azab MS, Goda H. Correlation of T.vaginalis to bacterial vaginosis; a laboratory-based study. J Infect Dev Ctries. 2010; 29(4): 156-63. 